\title{
PENINGKATAN DISIPLIN KERJA PEGAWAI DI SEKRETARIAT DAERAH KOTA PALU PROVINSI SULAWESI TENGAH
}

\author{
Fierda Hidayat*); Muchlis Hamdi; Rossy Lambelanova \\ Pascasarjana Institut Pemerintahan Dalam Negeri Jakarta \\ *)email: fierdahidayat@ymail.com
}

Paper Accepted: 30 Juni 2021

Paper Reviewed: 01-08 Juli 2021 Paper Edited: 09-16 Juli 2021

Paper Approved: 19 Juli 2021

\begin{abstract}
ABSTRAK
Penelitian ini dilakukan untuk menganalisis disiplin kerja pegawai di Sekretariat Daerah Kota Palu Provinsi Sulawesi Tengah dan untuk mengetahui faktor penghambat dan pendukung disiplin kerja pegawai, serta untuk mengetahui upaya yang dapat dilakukan dalam peningkatan disiplin kerja pegawai di Sekretariat Daerah Kota Palu Provinsi Sulawesi Tengah. Penelitian ini menggunakan wawancara dan pengambilan data pada Sekretariat Daerah Kota Palu Provinsi Sulawesi Tengah. Metode penelitian kualitatif dengan pendekatan deskriptif yang dilakukan dengan cara mengamati dan menganalisis serta menggambarkan permasalahan yang terjadi berdasarkan fakta yang ada di lapangan untuk dapat ditarik suatu kesimpulan yang pada akhirnya akan menghasilkan alternatif sebagai saran yang dapat digunakan untuk perbaikan kedepannya. Hasil penelitian menunjukkan bahwa Peningkatan disiplin kerja pegawai di lingkungan Sekretariat Daerah Kota Palu Provinsi Sulawesi Tengah dari aspek kehadiran masih rendah, hal ini ditunjukkan dengan adanya pegawai yang tidak mematuhi jam kerja. Dari aspek ketaatan pada peraturan kerja masih kurang, ini disebabkan masih adanya pegawai yang tidak memperhatikan peraturan kerja, begitu pun dilihat dari aspek tingkat kewaspadaan tinggi menunjukkan masih kurang baik, ini terlihat dari penggunaan fasilitas kantor oleh pegawai yang tidak pada tempatnya seperti pada waktu jam kerja, sehingga menyebabkan pekerjaan menjadi tertunda. Sedangkan dari segi ketaatan pada standar kerja sudah baik, hak ini terlihat pada proses pekerjaaan yang dilakukan dengan penuh tanggung jawab serta sesuai standar dengan mengacu pada petunjuk teknis yang ada, begitu pun dari segi bekerja etis juga sudah baik, hal ini terlihat dengan sudah banyak pegawai yang menunjukkan perilaku yang baik yakni bersikap ramah, saling menghormati terhadap sesame pegawai, serta bersikap sopan santun dalam memberikan pelayanan administrasi kepegawaian dengan mengedepankan sikap dan perilaku yang sesuai dengan etika.
\end{abstract}

Kata Kunci: Disiplin Kerja Pegawai

\section{PENDAHULUAN}

Disiplin kerja pegawai tentunya masih menjadi hal utama dalam pencapaian keberhasilan organisasi, tanpa suatu kedisiplinan dari pegawai kegiatan organisasi tidak akan terselesaikan dengan baik. Untuk memiliki pegawai yang disiplin kerjanya baik, tepat waktu dalam menyelesaikan pekerjaannya, dan bertanggung jawab penuh atas tugas, pokok dan fungsinya, maka perlu ditanamkan rasa kesadaran dalam pencapaian keberhasilan organisasi dan tanggung jawab terhadap tugastugas yang dikerjakan oleh masing-masing individu. Dalam rangka meningkatkan sumber daya manusia yang berkualitas dibutuhkan suatu kedisiplinan yang tinggi. Sebab tanpa disiplin kerja yang baik tidak akan dapat menghasilkan 
suatu hasil yang baik dalam pencapaian tujuan bersama..

Dalam upaya meningkatkan disiplin kerja Pegawai Negeri Sipil (PNS), Pemerintah Daerah Kota Palu Provinsi Sulawesi Tengah memiliki kewenangan sendiri untuk membuat suatu peraturan yang mengatur tentang disiplin kerja PNS di lingkungan Pemerintah Daerah Kota Palu. Oleh karena itu, Pemerintah Daerah Kota Palu membuat Peraturan Wali Kota Palu Nomor 3 Tahun 2013 yang mengatur tentang Disiplin Kerja Pegawai Negeri Sipil dilingkungan Pemerintah Daerah Kota Palu yang tujuannya adalah untuk meningkatkan profesionalitas dan meningkatkan kinerja guna kelancaran pelaksanaan tugas dan prestasi kerja pegawai. Namun pada kenyataanya dilapangan disiplin kerja PNS di lingkungan Pemerintah Daerah Kota Palu belum maksimal. Hal ini dapat dilihat oleh adanya PNS yang melakukan pelanggaran disiplin seperti tidak mengikuti apel pagi, terlambat datang ke kantor dan tidak masuk kantor tanpa keterangan sesuai dengan data absensi pegawai Sekretariat Daerah Kota Palu Provinsi Sulawesi Tengah.

Menurut Sumber: Sekretariat Daerah Kota Palu 2016 dan 2017 pada Triwulan IV Tahun 2016 tingkat kehadiran $(\mathrm{H})$ pegawai pada Sekretariat Daerah Kota Palu Provinsi Sulawesi Tengah adalah sebesar $86,00 \%$. Selain itu adapun juga besarnya tingkat pegawai dengan tanpa keterangan (TK) adalah sebesar 9,62\%. Sedangkan tingkat kehadiran $(\mathrm{H})$ pegawai Sekretariat Daerah Kota Palu Provinsi Sulawesi Tengah pada Triwulan IV di tahun 2017 yaitu sebesar $71,26 \%$. Selain itu, ketidakhadiran atau tanpa keterangan (TK) PNS pada Sekretariat Daerah Kota Palu Provinsi Sulawesi Tengah sebesar 21,13\%. Sehingga dapat dilihat bahwa persentase PNS yang hadir pada Tahun 2016 dan Tahun 2017 di Sekretariat Daerah Kota Palu Provinsi Sulawesi Tengah mengalami perubahan yaitu penurunan dengan persentase sebesar $14,74 \%$ sedangkan pegawai dengan tanpa keterangan pada Tahun 2016 dan Tahun 2017 mengalami perubahan yaitu peningkatan ketidakhadiran pegawai dengan persentase sebesar $11,51 \%$.

Selain itu, dilihat dari sumber Sekretariat Daerah Kota Palu tahun 2018 tingkat kehadiran (H) PNS Sekretariat Daerah Kota Palu Provinsi Sulawesi Tengah adalah sebesar $24,05 \%$, besarnya jumlah ketidakhadiran atau Tanpa Keterangan sebesar $67,37 \%$. Selain itu jumlah tingkat keterlambatan masuk kerja PNS pada Sekretariat Daerah Kota Palu Provinsi Sulawesi Tengah yaitu sebesar $4,12 \%$, dan jumlah PNS yang pulang sebelum waktu adalah sebesar
4,31\%. Hal ini menandakan bahwa masih terdapat banyaknya pegawai yang tidak masuk kerja, dan masih adanya keterlambatan pegawai, serta masih terdapat pegawai yang pulang sebelum waktu, tentunya ini merupakan suatu pelanggaran disiplin.

Dari data yang diperoleh pada Tahun 2018 di atas berbeda dengan absensi PNS tahun 2016 dan 2017, hal ini dikarenakan absensi PNS di tahun 2016 dan 2017 menggunakan absensi manual pada saat apel pagi dan menggunakan finger print pada saat masuk dan pulang kantor, tetapi finger print tersebut belum maksimal dalam penggunaannya, hal ini karena alat finger print tidak dilengkapi dengan software.

Berdasarkan pemaparan data di atas dapat dilihat bahwa pemerintah daerah Kota Palu telah berupaya dalam hal meningkatkan disiplin kerja pegawai, hal ini dapat dlihat oleh adanya imbauan yang sudah sangat jelas oleh Sekretaris daerah Kota Palu yang menyampaikan mengenai kedisiplinan dalam bekerja bagi para Pegawai di Sekretariat Daerah Kota Palu khususnya bagi para PNS dilingkungan Sekretariat Kota Palu. Akan tetapi berdasarkan temuan sumber yang telah dijabarkan diatas bahwa masih terdapat PNS di Sekretariat Kota Palu yang melanggar peraturaan dispin kerja. Selanjutnya berdasarkan Peraturan Walikota Palu Nomor 3 Tahun 2013 tentang Disiplin Kerja Pegawain Negeri Sipil di Lingkungan Pemerintah Daerah Kota Palu Pasal 5 dijelaskan bahwa "PNS wajib melaksanakan apel pulang kerja dalam lingkungan satuan kerjanya". Namun, tahun 2016, 2017, dan 2018 di atas hanya memperlihatkan absensi kehadiran dan ketidakhadiran pegawai saat apel pagi, tetapi tidak memperlihatkan adanya apel pulang kerja di Sekretariat Daerah Kota Palu Provinsi Sulawesi Tengah, hal ini tentunya tidak sesuai dengan Peraturan yang mengatur tentang Disiplin Kerja Pegawai Negeri Sipil dilingkungan Pemerintah Daerah Kota Palu tersebut. Selanjutnya Peraturan Wali Kota Palu nomor 3 tahun 2013 tentang Disiplin Kerja Pegawai Negeri Sipil dilingkungan Pemerintah Daerah Kota Palu dalam pasal 14 ayat (1) disebutkan bahwa PNS yang tidak dapat menyampaikan bukti alasan tidak masuk kerja sebagaimana dimaksud dalam pasal 13 dan tidak meminta izin atasan langsungnya sebagaimana dimaksud dalam pasal 12 ayat (2) dinyatakan melanggar ketentuan disiplin kerja.

Dilansir pada Radar Sulteng Online tanggal 3 Januari 2018 di Kota Palu, bahwa usai libur banyak Aparatur Sipil Negara (ASN) berkeliaran di jam dinas. Dari pantauan Radar Sulteng, misalnya di warung PKL di jalan 
Balaikota Selatan, Kelurahan Tanamodindi, Kecamatan Palu Selatan, puluhan PNS dilingkup Pemerintah Kota Palu dilingkungan sekitar kantor Sekretariat Daerah Kota Palu tampak memenuhi warung, padahal belum masuk di jam istirahat.".

Fenomena ini juga di dasarkan pada salah satu Identifikasi permasalahan mengenai Pemerintahan Umum di Kota Palu yang dilihat pada Rencana Pembangunan Jangka Menengah Daerah Kota Palu Tahun 2016-2021 di bagian hasil penelitian yang menjelaskan tentang "Isuisu strategis yang salah satu permasalahannya adalah Reward kurang diterapkan pada proses Pengawasan". Dengan demikian, disiplin kerja yang tidak diikuti dengan reward akan membuat disiplin kerja PNS menjadi hilang dimasa yang akan datang.

Pemerintah Kota Palu Provinsi Sulawesi Tengah memberikan kompensasi dalam bentuk Tambahan Penghasilan berdasarkan beban kerja dan kondisi kerja PNS yang dananya bersumber dari Anggaran Pendapatan dan Belanja Daerah. Tambahan Penghasilan berdasarkan beban kerja yang ditetapkan Pemerintah Kota Palu tersebut dituangkan dalam Peraturan Wali Kota Nomor 35 Tahun 2015 tentang Pemberian Tambahan Penghasilan Pegawai Negeri Sipil dalam lingkungan Pemerintah Daerah Kota Palu. Tujuan Pemerintah Daerah Kota Palu Provinsi Sulawesi Tengah memberikan Tambahan Penghasilan berdasarkan beban kerja kepada pegawainya dalam rangka upaya meningkatkan kesejahteraan, dan pelayanan kepada masyarakat.

Pemberian Tambahan Penghasilan kepada setiap pegawai akan berhasil dan mampu meningkatkan semangat kerja pegawai apabila diberikan sesuai dengan beban kerjanya. Hubungan antara pegawai dan organisasi akan saling mendukung sehingga tujuan organisasi tercapai dan pegawai menjadi termotivasi dan sejahtera. Akan tetapi dilapangan masih terdapat PNS yang tidak menduduki jabatan struktural kurang termotivasi dalam kedisiplinan kerja. Penulis menemukan dari hasil penelitian Maryadi tahun 2012 dan penelitian Rasyidi tahun 2013 di Jurnal Sains Manajemen Volume 2 No. 2 Juni 2016 yang meneliti mengenai Disiplin Kerja PNS membuktikan bahwa tunjangan berpengaruh terhadap disiplin kerja PNS..

Berdasarkan uraian permasalahan tersebut di atas, maka penulis tertarik untuk melakukan penelitian mengenai Peningkatan Disiplin Kerja Pegawai di Sekretariat Daerah Kota Palu Provinsi Sulawesi Tengah.

\section{Perumusan Masalah}

Berdasarkan uraian diatas, maka pokok permasalahan yang akan diteliti dalam penelitian ini yaitu sebagai berikut :

1. Bagaimana Disiplin Kerja Pegawai di Sekretariat Daerah Kota Palu Provinsi Sulawesi Tengah?

2. Apa faktor pendukung dan penghambat Disiplin Kerja Pegawai di Sekretariat Daerah Kota Palu Provinsi Sulawesi Tengah?

3. Apa upaya Peningkatan Disiplin Kerja pegawai di Sekretariat Daerah Kota Palu Provinsi Sulawesi Tengah?

\section{Tujuan Penelitian}

Berdasarkan perumusan masalah yang telah di uraikan di atas, maka penelitian ini bertujuan sebagai berikut :

1. Mengetahui Disiplin Kerja Pegawai di Sekretariat Daerah Kota Palu Provinsi Sulawesi Tengah.

2. Menganalisis faktor penghambat dan pendukung Disiplin Kerja Pegawai di Sekretariat Daerah Kota Palu Provinsi Sulawesi Tengah.

3. Mengetahui upaya yang dapat dilakukan dalam Peningkatan Disiplin Kerja Pegawai di Sekretariat Daerah Kota Palu.

\section{Tinjauan Teoritis}

\section{Teori Konsep Pemerintahan Daerah}

Menurut Hamdi (2002:125) Pemerintahan sebagai suatu aktivitas, proses dan institusi yang terbentuk atas dasar kesepakatan. Menurut Labolo (2006:20) pemerintahan menunjukan pada aktivitas kekuasaan dalam berbagai ranah publik. Sedangkan menurut Gie (2000:5) "Pemerintah Daerah satuan-satuan organisasi pemerintah yang berwenang untuk menyelenggarakan segenap kepentingan setempat dari sekelompok yang mendiami suatu wilayah yang dipimpin oleh kepala pemerintah daerah yang dipilih secara demokrasi”.

Berdasarkan definisi di atas, dapat disimpulkan bahwa pemerintah daerah merupakan suatu proses kegiatan penyelenggaraan pemerintahan di daerah yaitu sebagai pelaksana semua kegiatan yang mengatur jalannya semua pemerintahan yang ada di daerah berdasarkan tugas dan fungsi pemerintah daerah.

\section{Teori Konsep Sumber Daya Manusia}

Menurut Hasibuan (2016:10) menyatakan bahwa manajemen Sumber Daya Manusia (MSDM) adalah "ilmu dan seni mengatur 
hubungan dan peranan tenaga kerja agar efektif dan efesien membantu terwujudnya tujuan perusahaan, karyawan dan masyarakat". Sedangkan menurut Serdamayanti (2010:25) menyatakan bahwa manajemen Sumber Daya Manusia (MSDM) adalah "Rancangan sistem formal dalam organisasi untuk memastikan penggunaan bakat manusia secara efektif dan efesien guna mencapai tujuan organisasi”.

Selain itu menurut Sutrisno (2017:6) mengemukakan bahwa manajemen Sumber Daya Manusia (MSDM) adalah "kegiatan perencanaan, pengadaan, pengembangan, pemeliharaan, serta penggunaan SDM untuk mencapai tujuan baik secara individu maupun organisasi".

Berdasarkan pengertian dari Manajemen Sumber Daya Manusia (MSDM) menurut beberapa ahli diatas, maka dapat dikatakan bahwa manajemen sumber daya manusia adalah salah satu bidang manajemen yang secara khusus mengatur peranan manusia dalam mewujudkan tujuan organisasi.

\section{Konsep Disiplin Kerja}

Menurut Sulistiyani dan Rosidah (2009:290) "disiplin (discipline) adalah prosedur yang mengoreksi atau menghukum bawahan karena melanggar peraturan atau prosedur. Disiplin merupakan bentuk pengendalian diri pegawai dan pelaksanaan yang teratur dan menunjukan tingkat kesungguhan tim kerja di dalam sebuah organisasi".

Selanjutnya, menurut Rivai dalam Sinambela (2018:355), yang menjelaskan bahwa disiplin kerja memiliki beberapa komponen yaitu:

1. Kehadiran.

Hal ini menjadi indikator yang mendasar untuk mengukur kedisiplinan.

2. Ketaatan pada peraturan kerja. Pegawai yang taat pada peraturan kerja tidak akan melalaikan prosedur kerja dan akan selalu mengikuti pedoman kerja yang ditetapkan oleh perusahaan.

3. Ketaatan pada standar kerja.

Hal ini dapat dilihat melalui besarnya tanggung jawab pegawai terhadap tugas yang diamanahkan kepadanya.

4. Tingkat kewaspadaan tinggi. Pegawai memiliki kewaspadaan tinggi akan selalu penuh perhitungan dan ketelitian dalam bekerja, serta selalu menggunakan sesuatu secara efektif dan efisien.

5. Bekerja etis.

Merupakan salah satu bentuk tindakan indisipliner sehingga bekerja etis sebagai salah satu wujud dari disiplin kerja pegawai.

Dari teori di atas penulis menggunakan teori Rivai dalam Sinambela (2018:355) yang akan menjawab dari beberapa komponen disiplin kerja pegawai. Yang diantaranya yaitu kehadiran, bahwa kehadiran tentunya menjadi indikator yang mendasar untuk mengukur kedisiplinan pegawai. Ketaatan pada peraturan kerja sangat penting untuk dilaksanakan dalam organisasi pemerintahan karena pegawai yang taat pada peraturan kerjanya tentunya tidak akan melalaikan prosedur kerja yang sudah ditetapkan dalam peraturan yang berlaku. Kemudian ketaatan pada standar kerja yang menjadi yang menjadi suatu tanggung jawab semua pegawai pemerintahan karena melalui besarnya tanggung jawab pegawai akan kerjanya tentunya merupakan suatu kedisiplinan kerja yang baik.

Selanjutnya, tingkat kewaspadaan yang tinggi dalam hal ini juga diperlukan karena dalam disiplin kerja yang baik pegawai harus penuh perhitungan dan ketelitian dalam bekerja, secara efektif dan efisien, sehingga kedisiplinan kerjapun menjadi baik. Dan terakhir bekerja etis merupakan hal yang terpenting dalam dunia kerja karena akan menciptakan suasana yang baik dilingkungan kerjanya sehingga bekerja etis sebagai salah satu wujud dari disiplin kerja pegawai.

Menurut Saydam (2000:291), faktor-faktor yang mempengaruhi disiplin pegawai adalah:

1. Besar kecilnya pemberian kompensasi. Para karyawan akan mematuhi segala peraturan yang berlaku, bila ia merasa mendapat jaminan balas jasa yang setimpal dengan jerih payahnya yang telah dikontribusikan bagi organisasi.

2. Ada tidaknya keteladanan pimpinan dalam perusahaan.

Keteladanan pimpinan sangat penting sekali, karena lingkungan organisasi, semua karyawan akan selalu memperhatikan pimpinanya dalam menahkodai organisasi

3. Ada tidaknya aturan pasti yang dapat dijadikan pegangan.

Pembinaan disiplin tidak akan dapat dilaksanakan dalam organisasi, bila 
tidak ada aturan tertulis yang pasti untuk dapat dijadikan pegangan bersama.

4. Keberanian pimpinan dalam mengambi tindakan.

Bila ada seseorang karyawan yang melanggar disiplin, maka perlu ada keberanian pimpinan untuk mengambil tindakan yang sesuai dengan tingkat pelanggaran yang dibuatnya.

5. Ada tidaknya pengawasan pimpinan.

Dalam setiap kegiatan yang dilakukan oleh organisasi perlu adanya pengawasan, agar dapat melaksanakan pekerjaan dengan tepat dan sesuai dengan yang telah ditetapkan.

6. Ada tidaknya perhatian kepada para karyawan.

Seorang karyawan tidak hanya puas dengan penerimaan kompensasi yang tinggi, namun adanya timbal balik sikap dari pemimpinanya.

7. Diciptakan kebiasaan-kebiasaan yang mendukung tegaknya disiplin.

Kebiasaan-kebiasaan positif itu antara lain:

Saling menghormati bila ketemu di lingkungan pekerjaan., melontarkan pujian sesuai dengan tempat dan waktunya sehingga para karyawan akan turut merasa bangga dengan pujian tersebut., sering mengikutsertakan karyawan dalam pertemuan-pertemuan, apalagi pertemuan yang berkaitan dengan nasib dan pekerjaan mereka, memberi tahu bila ingin meninggalkan tempat kepada rekan sekerja, dengan menginformasikan, ke mana dan untuk urusan apa, walaupun kepada bawahan sekalipun.

\section{Konsep Motivasi, Reward dan Punishment}

Martoyo (2000:164) mengatakan bahwa "motivasi atau motivation berarti pemberian motif, penimbulan motif atau hal yang menimbulkan dorongan atau keadaan yang menimbulkan dorongan. Dapat juga dikatakan bahwa motivation adalah faktor yang mendorong orang untuk bertindak dengan cara tertentu". Martoyo (2000:165) juga mengatakan bertolak dari arti kata motivasi tadi, maka yang dimaksud dengan "motivasi kerja adalah sesuatu yang menimbulkan dorongan atau semangat kerja. Atau dengan kata lain pendorong semangat kerja".
Banyak pakar ahli yang menghubungkan kedisiplinan dan motivasi. Menurut Fahmi (2016:71) bahwa "motivasi adalah aktivitas perilaku yang bekerja dalam usaha memenuhi kebutuhan-kebutuhan yang diinginkan". Sedangkan, menurut Purwanegara dkk (2009:148) "motivasi adalah daya dorong yang ada pada diri seseorang yang menimbulkan orang tersebut melakukan kegiatan-kegiatan tertentu untuk mencapai tujuannya". Purwanegara dkk (2009:148) juga mengatakan bahwa organisasi terdiri dari beberapa orang anggota dengan kebutuhan dan keinginan serta sifat yang berbeda-beda. Oleh karena itu, maka motivasi (motivation) adalah merupakan masalah yang kompleks dalam organisasi.

Dari beberapa pengertian diatas dapat disimpulkan bahwa dengan adanya pemberian kompensasi maka organisasi secara langsung ikut memperhatikan motivasi kerja dan kesejahteraan pegawai, akan tetapi apabila kompensasi yang tidak adil, dan tidak mampu mensejahterakan pegawai akan memicu rendahnya motivasi dan semangat kerja pegawai.

\section{METODOLOGI PENELITIAN}

Metode yang digunakan dalam penelitian ini adalah Metode deskriptif dengan pendekatan induktif. Menurut Moleong (2011:11), metode deskriptif adalah "data yang dikumpulkan berupa kata-kata, gambar dan bukan angkaangka. Hal itu disebabkan oleh adanya penerapan metode kualitatif. Selain itu, semua yang dikumpulkan berkemungkinan menjadi kunci terhadap apa yang sudah diteliti”. Menurut pendapat Sugiyono (2011:15), mengartikan tentang penelitian kualitatif yaitu :

Metode penelitian kualitatif adalah metode penelitian yang berlandaskan pada filsafat postpositivisme, digunakan untuk meneliti pada kondisi objek yang alamiah, (sebagai lawannya adalah eksperimen) dimana peneliti adalah sebagai instrumen kunci, pengambilan sampel sumber data dilakukan secara purposive dan snowbal, teknik pengumpulan dengan trianggulasi (gabungan), analisis data bersifat induktif / kualitatif dan hasil penelitian kualitatif lebih menekankan makna dari pada generalisasi.

\section{Teknik Pengumpulan Data}

Sugiyono (2011:193), menyatakan pengumpulan data dapat menggunakan data primer dan data sekunder :

\section{a. Data Primer}

Data primer adalah yang langsung dari responden yang sifatnya sangat subyektif 
karena merupakan persepsi pribadi, data primer dihimpun secara langsung dari informan melalui pengamatan dan wawancara langsung maupun wawancara semistruktur baik tak berstruktur.

Disiplin kerja merupakan kepatuhan pegawai terhadap seluruh aturan yang ada di tempat kerja. Dalam hal peningkatan disiplin kerja pegawai tentunya diperlukan suatu perubahan dalam meningkatkan kedisiplinan itu sendiri, karena itu dalam penelitian ini sumber data primer diperoleh dari hasil wawancara dengan informan.

\section{b. Data Sekunder}

Data sekunder adalah data yang diperoleh secara tidak langsung dari obyeknya. Biasanya ditemukan dalam jurnal, laporan, monografi dan hasil penelitian orang lain.

Adapun data sekunder yang diperlukan dalam penelitian ini adalah : Data tentang pembentukan Sekretariat Daerah Kota Palu, Standard Operating Prosedures (SOP), visi dan misi, struktur organisasi, tupoksi, absensi dan data lain yang diperlukan untuk penelitian

\section{PEMBAHASAN}

\section{Peningkatan Disiplin Kerja Pegawai di Sekretariat Daerah Kota Palu Provinsi Sulawesi Tengah}

Disiplin kerja memiliki peranan yang sangat penting dalam suatu organisasi, hal ini dikarenakan pada tingkat disipilin kerja tinggi maka akan diperoleh kinerja Pegawai Negeri Sipil yang baik. Dengan disiplin kerja yang tinggi diharapkan bisa menjadikan Pegawai Negeri Sipil mampu melaksanakan tugas dan pekerjaan dengan baik serta menciptakan suasana kerja yang menyenangkan, tertib dan teratur sehingga memperlancar tugas organisasi.

Dengan ditegakkannya disiplin kerja diharapkan Pegawai Negeri Sipil sesuai dengan peraturan yang berlaku dan dapat meningkatkan kualitas kerja yang baik sehingga visi dan misi organisasi dapat dicapai dengan baik. Adapun Visi Sekretariat Daerah Kota Palu Provinsi Sulawesi Tengah yaitu "Palu Kota Jasa Berbudaya dan Beradat dilandasi Iman dan Taqwa”. Sedangkan Misi Sekretariat Daerah Kota Palu Provinsi Sulawesi Tengah yaitu:

1. Terwujudnya Pemetaan Potensi Sumberdaya Kota Palu berbasis IT;

2. Peningkatan dan Pengembangan daya saing potensi Sumberdaya Manusia;

3. Kelurahan Inovasi Unggul dan Mandiri berbasis Iptek bagi Kemandirian Ekonomi Kerakyatan;
4. Rasionalisasi Birokrasi Pemerintah Kota Palu yang Efisien dan Efektif berbasis Budaya;

5. Penataan dan Pengembangan Infrastruktur Kota berbasis Wisata Budaya; dan

6. Revitalisasi Nilai-Nilai Budaya Bangsa.

Hal ini berarti bahwa dalam setiap aktifitasnya Pegawai Negeri Sipil selalu mengikuti pedoman kerja yang telah ditetapkan oleh organisasi serta dapat mempertanggung jawabkan semua kegiatan yang dilakukannya. Selain itu, Pegawai Negeri Sipil juga dituntut untuk bekerja seefektif dan seefisien sehingga tujuan organisasi dapat tercapai.

Adapun dimensi dari komponen disiplin kerja yaitu dalam penerapan kedisiplinan kerja pegawai, menurut Rivai dalam Sinambela (2018:355), terdapat 5 (lima) aspek kedisiplinan yakni tingkat kehadiran, ketaatan pada peraturan kerja, ketaatan pada standar kerja, tingkat kewaspadaan tinggi dan bekerja etis. Sehingga dimensi-dimensi tersebut menjadi patokan bagi penulis dalam melakukan penelitian di lapangan. Adapun hasil penelitian yang penulis lakukan adalah sebagai berikut:

\section{Kehadiran}

Kehadiran merupakan salah satu faktor dalam penilaian disiplin Pegawai Negeri Sipil. Kehadiran dalam pekerjaan merupakan perilaku yang mendukung aturan yang ditetapkan dalam suatu lembaga atau organisasi, karena dengan kehadiran tersebut maka pegawai akan dapat melakukan dan melaksanakan pekerjaannya dengan baik. Pelaksanaan pekerjaan akan menghasilkan capai dengan baik jika didalam pelaksanaannya Pegawai Negeri Sipil yang mengerjakan memiliki intensitas dalam menyelesaikannya melalui kehadirannya di Kantor.

Berdasarkan sumber Sekretariat Daerah Kota Palu 2016 dan 2017, pada triwulan IV tahun 2016 dari tabel tersebut dapat dilihat juga besarnya tingkat pegawai dengan tanpa keterangan (TK) adalah sebesar 9,62\%. Selain itu ketidakhadiran atau tanpa keterangan (TK) pegawai pada Sekretariat Daerah Kota Palu Provinsi Sulawesi Tengah pada triwulan IV di tahun 2017 yaitu sebesar 21,13\%. Sehingga dapat dilihat bahwa presentase pegawai yang tidak hadir mengalami perubahan peningkatan ketidakhadiran pegawai dengan presentase sebesar $11,51 \%$. Hal ini membuktikan bahwa masih ada peningkatan ketidakhadiran pegawai 
di Sekretariat Daerah Kota Palu Provinsi Sulawesi Tengah.

Adapun sumber Sekretariat Daerah Kota Palu 2018, diketahui bahwa tingkat ketidakhadiran aparatur di Sekretariat Daerah Kota Palu Provinsi Sulawesi Tengah 67,37\%, selain itu jumlah keterlambatan masuk kerja PNS pada Sekretariat Daerah Kota Palu Provinsi Sulawesi Tengah yaitu sebesar 4,12\% dan jumlah PNS yang pulang sebelum waktunya adalah sebesar 4,31\%. Hal ini dikaitkan dengan pernyataan dari beberapa informan tersebut bahwa memang pegawai di Sekretariat Daerah Kota Palu Provinsi Sulawesi Tengah ada yang masih datang terlambat dan ada yang pulang sebelum waktunya dan bahkan masih ada yang tidak masuk kantor tanpa keterangan yang jelas. Tentunya hal ini menandakan bahwa masih terdapat ada pegawai yang tidak masuk kerja, dan masih adanya keterlambatan pegawai, serta masih terdapat pegawai yang pulang sebelum waktunya, tentu ini merupakan suatu pelanggaran disiplin.

Penulis mendeskripsikan bahwa kehadiran Pegawai Negeri Sipil di Sekretariat Daerah Kota Palu Provinsi Sulawesi Tengah terdapat yang melanggar disiplin karena melanggar ketentuan jam kerja yang telah ditentukan oleh organisasi. Data absensi perlu ditindaklanjuti oleh atasan atau pimpinan dengan memberikan efek jera kepada pegawai yang memiliki tingkat kehadiran yang kurang baik. Dengan adanya tindakan pendisiplinan ini diharapkan akan memberikan motivasi untuk merubah perilakunya ke arah yang positif terkait dengan kehadirannya.

\section{Ketaatan pada Peraturan Kerja}

Ketaatan pada Peraturan Kerja setiap organisasi untuk menjalankan tugas dan fungsi setiap elemen atau unit organisasi. Pedoman atau acuan inilah yang sering disebut Standar Operasional dan Prosedur atau SOP dimana Standar Operasional Prosedur adalah dokumen yang berisi serangkaian instruksi tertulis yang dibakukan mengenai berbagai proses penyelenggaraan adminisitrasi perkantoran yang berisi cara melakukan pekerjaan. Peraturan dan tata tertib dibuat untuk menciptakan suatu kondisi yang lebih kondusif bagi semua pihak. Dalam hal ini peraturan tersebut dibuat untuk membuat kelancaran pekerjaan, sehingga apa yang menjadi tujuan organisasi dapat tercapai.

Bapak Asisten Administrasi Umum Sekretariat Daerah Kota Palu Provinsi Sulawesi Tengah, Bapak Imran Lataha, S.E, M.M, beliau mengatakan bahwa:

\begin{abstract}
"Kalau persoalan taat aturan atau tidaknya itu sangat jelas sudah ada aturan tertulisnya jadi saya rasa dari keperluan pegawai-pegawai disini yah terkadang ada yang sudah tidak balik kantor lagi dengan urusan hal pribadi setiap pegawai yang ada disini. Terkadang ada mungkin yang datang pagi menyelesaikan kerjanya setelah itu siangnya pada jam istirahat banyak pegawai yang kosong ruangan kerjanya apabila saya memantau ke ruangan-ruangan lainnya."
\end{abstract}

Selanjutnya Kepala Sub Bagian Pembinaan Aparatur Sekretariat Daerah Kota Palu Provinsi Sulawesi Tengah, Ibu Hj. Rosnah, S.H, M.H, beliau mengatakan:

"Terkadang yah ada pegawai yang meninggalkan kantor dengan alasan pribadi atau ada keperluan mendadak untuk meninggalkan kantor atau pekerjaannya, tapi ada yang balik lagi dan ada yang tidak balik lagi, itu tergantung dari urusan mereka masing-masing. Cuman kadang saya hanya memberikan teguran secara lisan apabila pegawai tersebut terus menerus"

Sesuai hasil pengamatan yang dilakukan, maka menguatkan hasil yang didapatkan, bahwa ketaatan terhadap peraturan kerja Pegawai Negeri Sipil Sekretariat Daerah Kota Palu Provinsi Sulawesi Tengah masih kurang, hal ini disebabkan masih adanya Pegawai Negeri Sipil yang tidak memperhatikan atau melalaikan peraturan kerja serta masih adanya Pegawai Negeri Sipil yang dalam menyelesaikan pekerjaan itu tidak tepat waktu seperti yang ditetapkan.

\section{Ketaatan pada standar kerja}

Ketaatan pada standar kerja hal ini dapat dilihat melalui besarnya tanggung jawab karyawan terhadap tugas yang diamanhkan kepadanya. Setiap pekerjaan harus ada standar yang merupakan tolok ukur keberhasilan seorang Pegawai Negeri Sipil dalam melaksanakan tugas dan fungsinya. Pegawai Negeri Sipil yang disiplin ditunjukkan pada salah satu kondisi dimana Pegawai Negeri Sipil tunduk dan mengikuti standar kerja yang ditetapkan.Oleh karena itu, untuk mengetahui ketaatan pada standar kerja di Sekretariat Daerah Kota Palu penulis melakukan wawancara dengan Sekretaris Daerah Kota Palu Provinsi Sulawesi Tengah, Bapak H. Asri Sawaya, S.H, beliau mengatakan bahwa: 
"Dalam hal tanggung jawab mengerjakan atau menyelesaikan pekerjaannya saya rasa pegawai di Sekretariat Daerah Kota Palu sudah dengan baik menyeleaikan pekerjaannya walaupun kadang ada yang belum tepat sasaran dengan masalah waktu yang ada, saya rasa tidak masalah asal pegawai menyelesaikan segala hal pekerjaan mereka masing-masing dengan baik sesuai dengan tugas dan fungsi pegawai-pegawai yang sudah sesuai dengan aturan yang ada."

Pernyataan di atas dapat dipertegas lagi dengan hasil wawancara oleh Kepala Bagian Organisasi Sekretariat Daerah Kota Palu, Bapak H. Wajib, M.Si, beliau mengatakan:

"Pegawai dalam hal menyelesaikan pekerjaannya sesuai dengan prosedur kerja yang ada tentunya, akan tetapi kadang saya melihat ada yang hanya menyalagunakan fasilitas komputer yang diberikan untuk menyelesaikan pekerjaan, ada yah biasa saya dapat hanya dipakai untuk menonton dan bermain Internet, tapi saya sudah sampaikan ke pegawai tersebut bahwa harus selesai dulu pekerjaan".

Berdasarkan hasil pengamatan, maka pemanfaatan fasilitas kantor yang semestinya digunakan untuk menunjuang kelancaran pekerjaan tidak dimanfaatkan dengan baik oleh Pegawai Negeri Sipil sebagaimana fungsinya masing-masing. Tentunya hal ini akan mempengaruhi iklim kerja di kantor tersebut. Mengingat dengan sikap Pegawai Negeri Sipil yang seperti itu, sehingga pekerjaan yang dilakukan selalu berulang-ulang karena adanya kesalahan yang justru mengakibatkan tidak adanya efisien waktu. Dari segi tingkat kewaspadaan tinggi Pegawai Negeri Sipil Sekretariat Daerah Kota Palu Provinsi Sulawesi Tengah menunjukkan masih kurang baik. Ini terlihat dari penggunaan fasilitas kantor yang tidak pada tempatnya.

\section{Tingkat Kewaspadaan Tinggi}

Tingkat kewaspadaan tinggi juga merupakan faktor yang menjadi perhatian dalam menilai disiplin Pegawai Negeri Sipil karena Pegawai Negeri Sipil yang selalu hati-hati dalam bertindak, penuh ketelitian dan menggunakan fasilitas kantor secara efisien khususnya dalam menjalankan tugasnya sehingga output yang dihasilkan sesuai dengan standar dan peraturan yang berlaku.

Untuk mengetahui tingkat kewaspadaan tinggi dalam efektif dan efesien dengan penggunaan sistem kehadiran pegawai, penulis melakukan wawancara dengan Sekretaris
Daerah Kota Palu Provinsi Sulawesi Tengah, Bapak H. Asri Sawaya, S.H, beliau mengatakan bahwa:

"Pada alat fingerprint dulunya memang belum ada sistem software-nya untuk mengetahui jam kehadiran pegawai, itu karena belum adanya anggaran untuk sistem tersebut, jadi kita biasa hanya pakai daftar hadir manual kalau pelaksanaan apel pagi. Dengan waktu kehadiran pegawai saya rasa belum efektif sebelum adanya software tahun 2018 ya pada alat fingerprint karena dengan penentuan waktu datangnya pegawai tidak diketahui kan, jadi dengan adanya alat fingerprint itu bisa dilihat jam berapa pegawai datang ke kantor dan jam berapa kan pulangnya, sehingga itu semua tentu sudah menjadi keharusan pegawai melaksanakan kedisiplinan yang memang tidak semaunya saja datang jam berapa denga pulang kantor jam berapa begitu, jadi terarah jam kehadirannya."

Penulis melakukan wawancara dengan pegawai Pembinaan Aparatur Sekretariat Daerah Kota Palu Provinsi Sulawesi Tengah,

Bapak Ibrahim, yang mengatakan bahwa:

"Alat fingerprint sebelum tahun 2018 ada sistem software di dalamnya jadi saya rasa belum cukup efektif dan efesien kalau pegawai memakai alat sidik jari soalnya kan percuma saya rasa tidak ditau jam kehadirannya, itupun kita disini ada absensi manual jadi semua pegawai kalau isi daftar hadir masih pake manual saja. Itu juga biasanya kalau mau merekap untuk dilaporkan sama kepala bagian organisasi pembayaran tambahan penghasilan pejabat biasa hanya saya rekap dari daftar kehadiran apel pagi, jadi tidak terpakai itu alat fingerprint karena itu belum ada softwarenya, jadi saya rasa di tahun sebelumnya tidak efektif kehadiran pegawai"

Selanjutnya dari hasil wawancara dan analisis data tersebut di atas, penulis dapat menarik kesimpulan bahwa sesuai dengan Perturan Wali Kota Palu Nomor 3 Tahun 2013 tentang Disiplin Kerja Pegawai Negeri Sipil dilingkungan Pemerintah Daerah Kota Palu belum sesuai dengan apa yang ada pada ketentuan aturan bahwa pegawai harus memakai alat fingerprint, namun kenyataanya sebelum tahun 2018 tentunya kehadiran pegawai tidak begitu efektif dalam penggunaan sistem alat kehadiran yaitu berupa alat fingerprint karena 
setiap jam masuk kantor tentu tidak diketahui waktu datangnya pegawai, dan waktu keterlambatan pegawai maupun waktu pulang mendahuluinya pegawai di Sekretariat Daerah Kota Palu Provinsi Sulawesi Tengah.

\section{Bekerja Etis}

Bekerja etis juga merupakan faktor yang menjadi perhatian dalam menilai disiplin kerja pegawai Negeri Sipil karena Pegawai Negeri Sipil yang ramah, saling menghargai dan menghormati serta jujur dalam pelaksanaan pekerjaan merupakan Pegawa Negeri Sipil yang disiplin. Tujauan organisasi tidak tercapai jika tidak ada hubungan kerja sama yang baik antar aparatur, adanya pembagian tugas yang jelas, untuk itu setiap pegawai dituntut untuk bekerja etis yang mencerminkan tingkat kedisiplinan pegawai negeri sipil.

Untuk mengetahui bekerja etis dalam suasana harmonis dalam meningkatkan disiplin kerja pegawai, penulis melakukan wawancara dengan Sekretaris Daerah Kota Palu Provinsi Sulawesi Tengah, Bapak Asri Sayawa, S.H, beliau mengatakan bahwa:

"Ada itu biasanya berselisih paham antar pegawai kan itu sudah ada biasa terjadi tapi dalam hal melayani sesama pegawai kita kan juga butuh keramahan, tidak akan tercipta disiplin kerja kalau pegawaipegawai tidak ada tercipta suatu keharmonisan antar pegawai. Nah itu bisa dibilang harus saling menghargai sesam pegawai, karena kita kan sama-sama bekerja dalam satu instansi jadi saya rasa harus itu ada terciptanya suasana yang harmonis untuk menciptakan disiplin kerja yang baik."

Hal tersebut dipertegas lagi dengan hasil wawancara oleh Kepala Bagian Sekretariat Daerah Kota Palu Provinsi Sulawesi Tengah, Drs. H. Wajib, M.Si, beliau mengatakan bahwa:

"Saya rasa kita di Sekretariat ini sudah berusaha untuk menciptakan kedisiplinan kerja yang itu dikatakan harmonis bila pegawai lainnya bisa bekerja sama dengan baik. Kan ada tugas-tugas yang kadang memang harus saling bantu-membantu dengan sesama pegawai, jadi bisa kita lihat juga cara melayani contohnya saja di Bagian Pembinaan Aparatur kan itu persoalan kepegawaian pegawai di Sekretariat sini dilayani semua dibagian itu, jadi ya tergantung bagaimana kita ramah terhadap orang lain atau sesama pegawai di Sekretariat ini."
Berdasarkan hasil wawancara diatas, dapat penulis menarik kesimpulan bahwa bekerja etis dalam suasana yang harmonis bagi pegawai di Sekretariat Daerah Kota Palu Provinsi Sulawesi Tengah sudah baik dalam hal menciptakan suasana yang harmonis dalam menciptakan kedisiplinan kerja pegawai. Baik itu dari atasan kebawahan, bawahan ke atasan bahkan ke pegawai-pegawai lainnya yang datang berurusan di Sekretariat Daerah Kota Palu Provinsi Sulawesi Tengah

Faktor Pendukung dan Penghambat Disiplin Kerja Pegawai di Sekretariat Daerah Kota Palu Provinsi Sulawesi Tengah

Kedisiplinan merupakan suatu hal yang menjadi tolok ukur untuk mengetahui apakah peran manajer atau pimpinan secara keseluruhan dapat dilaksanakan dengan baik atau tidak. Disiplin juga merupakan bentuk pengendalian diri Pegawai Negeri Sipil dan pelaksanaan yang teratur menunjukkan tingkat kesungguhan tim kerja dalam sebuah organisasi, tindakan disiplin menuntut adanya hukuman terhadap Pegawai Negeri Sipil yang gagal memenuhi standar yang ditentukan. Oleh karena itu tindakan disiplin tidak diterapkan secara sembarangan, melainkan memerlukan pertimbangan yang bijak.

Betapa pentingnya peranan faktor disiplin kerja didalam meningkatkan kinerja pegawai. Dengan melihat kondisi riil pada pengamatan awal di lapangan hal tersebut memiliki relevansi dengan kenyataan yang sesungguhnya melalui suatu kegiatan yang nyata di lapangan, dimana seringkali dijumpai bahkan pemerintah Kota Palu sudah sering melakukan inspeksi dadakan atau sidak terhadap kedisiplinan pegawai negeri sipil.

Dapat diketahui bahwa tingkat kedisiplinan pegawai masih tergolong belum optimal, dimana hal tersebut dapat dilihat dari masalah yang timbul dalam suatu kantor yaitu banyaknya Pegawai Negeri Sipil. Tidak adanya teguran yang tegas dari atasan jika ada Pegawai Negeri Sipil yang tidak disiplin, khususnya dalam penyelesaian target pekerjaan dengan berbagai alasan kemanusiaan.

\section{Kompensasi}

Kompensasi merupakan salah satu fungsi penting dalam manajemen sumber daya manusia (MSDM). Karena kompensasi merupakan salah satu aspek yang paling sensitif didalam hubungan kerja. Bahwa kompensasi yang tujuannya adalah untuk meningkatkan disiplin kerja pegawai dilingkungan Pemerintah Daerah Kota Palu Provinsi Sulawesi Tengah khususnya di Sekretariat Daerah Kota Palu. Sesuai 
peraturan tertulis Surat Keputusan Wali Kota Palu Tahun 2018 dapat dilihat bahwa aturannya sudah sangat jelas hanya pejabat struktural saja yang mendapatkan tambahan penghasilan dilingkungan Pemerintah Daerah Kota Palu khususnya Sekretariat Daerah Kota Palu Provinsi Sulawesi Tengah, sedangkan pegawai yang tidak menduduki jabatan struktural tidak mendapatkan tambahan penghasilan tersebut, sehingga hal ini dapat dilihat dengan tidak efektifnya peningkatan disiplin kerja pegawai Sekretariat Daerah Kota Palu apabila tambahan penghasilan hanya diberikan bagi yang memegang jabatan saja.

Kemudian dapat dilihat juga dari kriteria pembayaran tambahan penghasilan berdasarkan Peraturan Wali Kota Nomor 35 Tahun 2015 tentang Tambahan penghasilan Pegawai Negeri Sipil dilingkungan Pemerintah Kota Palu Provinsi Sulawesi Tengah penyelesaian tugas, pokok dan fungsi, akan tetapi pembayaran tambahan penghasilan di Sekretariat Daerah Kota Palu hanya membayarkan dari kehadiran apel pagi saja, sedangkan dari aturan tertulis tersebut menyebutkan penilaian yang berdasarkan juga pada pembayaran tambahan penghasilan tidak berdasarkan apel sore atau jam pulang kerja. Sehingga juga tidak efektifnya pemberian tambahan penghasilan, karena hanya dilihat dari kehadiran absensi manual apel pagi saja yang tentunya tidak berdasarkan aturan yang ada. Sama halnya juga pembayaran tambahan penghasilan hanya berdasarkan absensi kehadiran apel pagi tentunya tidak diketahui, karena presensi manual sering di salah gunakan yang juga tidak dapat diketahui bila pejabat struktural tersebut selama jam kerja berada di tempat kerja atau tidak. Dan tentunya bisa dikatakan belum sangat efektif bagi peningkatan disiplin kerja pegawai di Sekretariat Daerah Kota Palu Provinsi Sulawesi Tengah.

\section{Keteladanan Pimpinan}

Teladan pimpinan sangat berperan dalam menentukan kedisiplinan pegawai, karena pimpinan dijadikan teladan dan pabutan oleh para bawahannya. Pimpinan harus memberi contoh yang baik, berdisiplin yang baik, jujur, adil, serta sesuai kata dengan perbuatan. Jika menerapkan teladan pimpinan yang baik, kedisiplinan pada bawahan pun akan ikut baik Jika teladan pimpinan kurang baik (kurang disiplin) para bawahan pun akan kurang disiplin..

Dasar pemilihan merupakan soal pengaruh, pimpinan mempengaruhi dan orang lain dipengaruhi. Kepemimpinan itu sifatnya spesifik, khas diperlukan bagi suatu situasi khusus. Sebab dalam suatu kelompok yang melakukan aktivitas-aktivitas tertentu, dan mempunyai suatu tujuan serta peralatanperalatan yang khusus. Pemimpin kelompok dengan ciri-ciri karakteristik itu merupakan fungsi dari situasi khusus.

Untuk mengetahui keteladanan pimpinan menyangkut dari aspek kedisiplinan kerja pegawai, penulis melakukan wawancara dengan Sekretaris Daerah Kota Palu Provinsi Sulawesi Tengah yaitu Bapak H. Asri Sawaya, S.H, beliau mengatakan bahwa:

"Saya rasa tingkat disiplin atasan di Sekretariat ini sudah baik walaupun ada biasanya kan tugas-tugas yang harus diurus bukan hanya selalu dikantor saja. Kalau dalam menindak tegas pegawai saya rasa itu sudah sesuai dengan aturan yang ada ya, kalau pegawai yang melanggar aturan disiplin tentunya ada sanksinya sesuai aturannya."

Terlihat jelas bahwa sikap dan perilaku pimpinan merupakan suatu cerminan untuk para pegawai dalam bersikap, karena seorang pemimpin akan menjadi contoh bagi pegawainnya. Jika pemimpin memberikan contoh yang baik maka pegawai pun akan ikut melakukan hal yang sama. Sebaliknya jika pemimpin semena-mena dalam bersikap maka bawahannya pun akan ikut melakukan hal yang sama dan tentunya akan berimbas kepada pekerjaannya.

\section{Peraturan Disiplin Kerja}

Disiplin yang baik adalah disiplin diri. Kecenderungan orang normal adalah melakukan apa yang menjadi kewajibannya dan menempati aturan permainan. Dalam aturan disiplin kerja pegawai di Sekretariat Daerah Kota Palu sudah sangat jelas ada aturannya pada peraturan Wali Kota Palu Nomor 3 Tahun 2013 tentang Disiplin Kerja Pegawai Negeri Sipil dilingkungan Pemerintah Daerah Kota Palu.

Maka penulis melakukan wawancara dengan Sekretaris Daerah Kota Palu Provinsi Sulawesi Tengah, Bapak H. Asri Sawaya, S.H, beliau mengatakan bahwa:

"Sejauh ini memang kita di Sekretariat ini belum melaksanakan apel sore hanya apel pagi saja. Kalau untuk pengisian daftar hadir kembali penerapannya disini itu semua tergantung dari bagian masingmasing atau ada penerapannya di bagian kepegawaian di organisasi yang mengurus absensi pegawai Sekretariat. Mengenai sanksi yang diberikan kepada pegawai 
yang melanggar aturan disiplin itu sudah jelas ya dibagian pembinaan aparatur ada banyak sanksi yang diberikan berupa teguran tertulis kepada pegawai-pegawai yang tidak berdisiplin, itu semua sudah ada aturannya bilamana ada pegawai yang melanggar jam kerja maka akan ditindak sesuai dengan aturan yang ada. Jadi saya rasa kalau pegawai yang sudah ditindak atau diberi teguran tertulis tapi tidak mengindahkan atau tidak mempedulikan tetap dengan melanggar jam kerja itu akan kita tindak lanjuti."

Dapat diketahui bahwa mengenai peraturan disiplin tentang kepastian aturan dan sanksi di Sekretariat Daerah Kota Palu masih belum menerapkan ketentuan peraturan yang ada, hal ini dapat dilihat pada peraturannya yaitu pada Peraturan Wali Kota Palu Nomor 3 Tahun 2013 tentang Disiplin Kerja Pegawai Negeri Sipil dilingkungan Pemerintah Daerah Kota Palu pasal 5 dijelaskan bahwa "PNS wajib melaksanakan apel pulang kerja dalam lingkungan satuan kerjanya". Namun dari absensi atau daftar kehadiran pegawai di Sekretariat Daerah Kota Palu Provinsi Sulawesi Tengah hanya mengisi daftar hadir saat pelaksanaan apel pagi, tetapi tidak memberlakukan adanya apel sore atau apel pulang kerja sesuai dengan Peraturan Wali Kota Palu Nomor 3 Tahun 2013 tentang Disiplin Kerja Pegawai Negeri Sipil dilingkungan Pemerintah Daerah Kota Palu Provinsi Sulawesi Tengah.

Kemudian mengenai sanksi atau pelanggaran disiplin sudah jelas dalam peraturan Wali Kota Palu Nomor 3 tahun 2013 tentang Disiplin Kerja Pegawai Negeri Sipil dilingkungan Pemerintah Daerah Kota Palu pada BAB IV pasal 14 ayat (2) disampaikan bahwa "PNS yang melanggar ketentuan disiplin kerja sebagaimana dimaksud pada ayat (1), dijatuhkan sanksi sesuai peraturan perundangundangan yang mengatur tentang disiplin PNS." Hal ini sudah diketahui bahwa dari pernyataan diatas pimpinan di Sekretariat Daerah Kota Palu sudah sangat menekankan pegawai-pegawai yang melanggar peraturan disiplin kerja sesuai peraturan perundang-undangan yang berlaku, hanya saja ada beberapa pegawai yang memang tidak peduli dengan sanksi-sanksi yang sudah diberikan melalui teguran tertulis.

Penulis dapat menarik kesimpulan bahwa peraturan disiplin kerja merupakan keharusan yang harus ditaati aturan-aturannya. Sebagaimana peraturan Wali Kota Palu Nomor 3 tahun 2013 tentang Disiplin Kerja Pegawai
Negeri Sipil dilingkungan Pemerintah Daerah Kota Palu yang dalam aturan tersebut sudah jelas dilihat bahwa ada aturan pemberlakuan apel dan ada aturan mengenai harus adanya laporan absensi kehadiran pegawai Sekretariat Daerah Kota Palu yang harus dikoordinasikan ke Badan Kepegawaian Daerah Kota Palu, dan juga sesuai dengan peraturan perundangundangan yang mengatur tentang disiplin kerja pegawai maish ada pegawai yang dikenakan sanksi-sanksi berupa teguran secara tertulis di tahun 2017. Akan tetapi dari semua peraturanperaturan yang ada belum bisa diterapkan di Sekretariat Daerah Kota Palu.

\section{Ketegasan Pimpinan}

Sekretariat Daerah Kota Palu Provinsi Sulawesi Tengah sebagai unsur pembantu pimpinan pemerintahan daerah, yang dipimpin oleh sekretaris daerah, yang dimana dalam hal penerapan kedisiplinan pegawai Sekretariat Daerah Kota Palu harus ada ketegasan pimpinan di dalamnya sehingga itu dapat dilihat dari aturan yang sudah ada dengan ketegasan pimpinan menjalankan peraturan sesuai dengan norma-norma yang berlaku. Oleh karena itu, untuk mengetahui ketegasan pimpinan dalam hal tindakan pimpinan penulis menganalisis tindakan pimpinan mengenai kedisiplinan pegawai Sekretariat Daerah Kota Palu Provinsi Sulawesi Tengah melalui wawancara dengan Asisten Administrasi Umum Sekretariat Daerah Kota Palu Provinsi Sulawesi Tengah, Bapak Imran Lataha, S.E, M.M, beliau mengatakan bahwa:

"Seorang pimpinan dalam satu organisasi perlu bersikap tegas, perlu ketegasan dalam arti tetap memegang pada aturanaturan yang ada dalam organisasi itu. Aturan sudah jelas mengatakan kapan waktunya kerja, kapan waktunya istirahat pulang dan saya yakin setiap pegawai paham betul akan hal ini hanya saja pelaksanaannya butuh kesadaran dan ketegasan dari pimpinan. ”.

Sedangkan menurut salah satus pegawai di Bagian Pembinaan Aparatur Sekretariat Daerah Provinsi Sulawesi Tengah, Bapak Ibrahim mengatakan bahwa:

"Pimpinan ditempat saya kerja sini sudah cukup tegas, apalagi tegas terhadap pegawai yang bertindak indispliner, karena sebagai pimpinan memang harus tegas dalam menjalankan kepemimpinannya, sikap pimpinan yang tegas pun akan membantu kedisiplinan para pegawai disini." 
Dari hasil wawancara tersebut, penulis dapat menarik kesimpulan bahwa ketegasan pimpinan dalam hal tindakan pimpinan melakukan tindakan yang memberikan sanksi bagi pegawai yang melanggar disiplin kerja dapat dikatakan terbilang cukup baik, karena dari pelaksanaan peraturan pemerintah nomor 53 tahun 2010 tentang disiplin pegawai negeri sipil sudah dilaksanakan dengan memberi sanksi-sanksi kepada pegawai yang melanggar aturan disiplin kerja pegawai. Maka dari itu tindakan dari atasan di Sekretariat Daerah Kota Palu bisa dikatakan cukup baik, namun pada kenyataannya tidak semua pemimpin dapat berlaku tegas terhadap pegawainya. Akibatnya pegawai akan bekerja dan bertindaks sesuka hati mereka dan menghasilkan kinerja yang buruk.

\section{Pengawasan}

Pengawasan seorang pimpinan dilakukan secara langsung kepada para pegawainya dan efektif untuk mencegah atau mengetahui kesalahan, memelihara kedisiplinan, meningkatkan prestasi kerja, mengaktifkan peranan atasan dan bawahan, menggali sistemsistem kerja yang paling efektif serta menciptakan sistem internal kontrol yang baik dalam mendukung terwujudnya tujuan instansi, pegawai dan masyarakat seperti yang diungkapkan oleh Sekretaris Daerah Kota Palu Provinsi Sulawesi Tengah, Bapak H. Asri Sawaya, S.H, beliau mengatakan bahwa:

"Kalau pada ada hari-hari tertentu itu kita bentuk tim untuk memantau nah kita terlibat selain dari kita disini misalnya saya, BKD bahkan Pak Wali, sendiri kita berapa kali turun bersama-sama ada BKD-nya ada Inspektorat dengan bagianbagian jadi kita membentuk tim untuk memantau, sekarang juga masih tetap juga jalan itu ada juga tim mereka interen turun memantau di BKD itu cuman saya tidak tau apakah mereka dalam bentuk keputusan kepala BKD katanya dalam bentuk surat tugas, mereka biasanya turun-turun ke OPD apakah benar-benar ada orang ini mau apel kemudian hadir diruangan, cuma karena biasanya ada alasan-alasan tertentu dari pegawai karena kita tidak bisa paksa orang masuk kantor."

Selain itu penulis juga melakukan wawancara dengan salah satu pegawai di Sekretariat Daerah Kota Palu Provinsi Sulawesi Tengah, yaitu Ibu Sri Agustina Rahim, S.E, beliau mengatakan bahwa:
"Ya, pengawasan pada pegawai pasti ada lah yah misalnya mengawasi langsung pegawainnya kalau sedang bekerja, biar pegawainnya juga cepat mengerjakan tugas yang diberikan, soalnya begini yah kadang ada saja pegawainya yang terlalu santai untuk mengerjakan tugas-tugas, biasanya atasan saya bekerja selalu mengawasi pegawainnya secara langsung. Kalau untuk pimpinan memonitoring pegawai biasa ada itu tapi kalau hari setiap selesai libur panjang pasti ada pejabat-pejabat keliling memonitoring disini."

Dari hasil wawancara tersebut, penulis dapat menarik kesimpulan bahwa di Sekretariat Daerah Kota Palu Provinsi Sulawesi Tengah, sudah mengikuti peraturan yang berlaku sesuai dengan Peraturan Wali Kota Palu Nomor 3 Tahun 2013 tentang Disiplin Kerja Pegawai Negeri Sipil dilingkungan Pemerintah Daerah Kota Palu khususnya di Sekretariat Daerah Kota Palu Provinsi Sulawesi Tengah.

\section{Perhatian Pimpinan}

Berhasil atau tidaknya sebuah organisasi/kantor sangat ditentukan oleh efektif atau tidaknya seorang pemimpin dalam menjalankan roda kehidupan organisasi/kantor tersebut. Dalam hal reward berupa hadiah untuk meningkatkan kesejahteraan yang juga disebut penghargaan dan dapat didefenisikan sebagai setiap bentuk penghargaan yang diberikan kepada pegawai sebagai balas jasa yang mereka berikan kepada organisasi/kantor. Sehingga perhatian pimpinan sangat diharapkan untuk pegawai di Sekretariat Daerah Kota Palu Provinsi Sulawesi Tengah, dalam hal prestasi kerja dan reward atau penghargaan, penulis melakukan wawancara dengan Sekretaris Daerah Kota Palu Provinsi Sulawesi Tengah, yaitu Bapak H. Asri Sawaya, S.H, beliau mengatakan bahwa:

"Itu yang kita masih harus berikan pemberian reward itu harusnya orang yang berprestasinya bagus itu harus diberikan reward. Tapi kita bukan melihat pangkat tapi melihat kinerja, supaya memotivasi yang lainnya itu supaya dia bisa juga bisa meningkatkan kinerjanya, beda dengan dulu kalau dulu dilihat dulu dia punya pangkatnya padahal orangnya belum tentu kinerjanya bagus."

Sedangkan menurut Kepala Sub Pembinaan Aparatur Sekretariat Daerah Kota 
Palu Provinsi Sulawesi Tengah, Ibu Hj. Rosna, S.H, M.H, mengatakan bahwa:

"Sejauh ini memang belum ada semacam bentuk reward yang diberikan untuk pegawai disini tapi itu sangat bagus untuk bila ada dukungan dari pimpinan bagi yang berprestasi dalam kerjanya apalagi yang bersiplinnya baik, sudah pasti akan diberikan apresiasi. Namun ada memang pegawai yang belum mengerti akan pekerjaannya, kita selalu memberikan arahan dan bimbingan kepada pegawai yang memang belum bisa memahami pekerjaannya dengan baik."

Dari hasil wawancara dan analisis data tersebut di atas, penulis dapat menarik kesimpulan bahwa Perhatian Pimpinan dalam hal pretasi kerja yang tentunya ada reward atau penghargaan bagi pegawai di Sekretariat Daerah Kota Palu Provinsi Sulawesi Tengah belum berjalan efektif sesuai dengan aturan yang telah ditetapkan yakni dalam pemberian penghargaan bagi pegawai yang berprestasi dalam hal disiplin kerjanya.

\section{Kebiasaan-kebiasaan Tegaknya Disiplin}

Sekretariat Daerah Kota Palu Provinsi Sulawesi Tengah sudah berupaya menerapkan peraturan mengenai disiplin kerja untuk meningkatkan motivasi kerja pegawai. Sehingga untuk mengetahui kebiasaan-kebiasaan tegaknya disiplin yang menyangkut saling menghormati, motivasi kerja dan lingkungan kerja di Sekretariat Daerah Kota Palu Provinsi Sulawesi Tengah. Penulis melakukasn wawancara dengan Sekretaris Daerah Kota Palu Provinsi Sulawesi Tengah, yaitu Bapak H. Asri Sawaya, S.H, beliau mengatakan bahwa:

"Ya memang itu juga ada kendala disiplin, etika itu yang kita sekarang ini saya bandingkan dengan kita-kita yang dulu itu sangat menghormati atasan kita kalau sekarang ini saya liat sudah dierareformasi saya liat sudah itu agak boleh dikatakan degradasi kita dengan itu etika, jadi kurang mengahrgai biasanya atasannya secara pemerintah harus menghargai yang diatas tidak boleh melihat usia nah itu yang saya liat agak dan ini juga karena dia muda segan menegur yang dibawah ini karena usia, jadi saya bilang itu tidak boleh begitu”.

Selain itu penulis juga melakukan wawancara dengan salah satu Kepala Bagian Sekretariat Daerah Kota Palu Provinsi Sulawesi
Tengah, yaitu Ibu Muliati, S.H, M.M, M.H, beliau mengatakan bahwa:

"Kadang ya ada pegawai yang memang kurang menghormati atasannya langsung bila sudah diberi teguran lisan misalnya kalau tidak masuk kerja atau sering pulang sebelum waktunya pulang itu biasanya ada seperti itu, pandangan saya sendiri motivasi yang diberikan pimpinan itu sudah baik bagi pelaksana atau penanggung jawab pada Jabatan yang di duduki itu sudah ada masing-masing porsinya berbeda-beda sesuai dengan peraturannya. Ya kalau kendala dalam penerapan disiplin kerja pegawai ya itu hanya dari pegawai itu sendiri yang kadang diberitau tapi tidak mendengarkan menyampaian-penyampaian pimpinan, jadi aturan-aturan yang sudah jelas ada tapi tetap dilanggar kan ada seperti itu wajar bagi pegawai.",

Dari wawancara tersebut, penulis dapat menarik kesimpulan bahwa dalam kebiasaankebiasaan tegaknya disiplin yang saling menghormati masih kurang di Sekretariat Daerah Kota Palu Provinsi Sulawesi Tengah, itu mungkin juga salah satu faktor penghambat disiplin kerja.

\section{Upaya Peningkatan Disiplin Kerja Pegawai di Sekretariat Daerah Kota Palu Provinsi Sulawesi Tengah}

Pengupayaan pengningkatan disiplin kerja pegawai yang mampu meningkatkan disiplin kerja pegawai di Sekretariat Daerah Kota Palu Provinsi Sulawesi Tengah adalah dengan berdasarkan pada upaya-upaya yaitu adanya upaya pimpinan atau pejabat struktural untuk selalu memberikan arahan atau himbauan kepada pegawai untuk selalu menaati Peraturan Disiplin Kerja, adanya upaya untuk melengkapi sistem software pada alat fingerprint, adanya upaya Pemerintah Kota Palu Provinsi Sulawesi Tengah untuk menganggarkan penambahan penghasilan bagi pegawai yang tidak menduduki Jabatan Struktural dalam lebih meningkatkan disiplin kerja pegawai di Sekretariat Daerah Kota Palu Provinsi Sulawesi Tengah, adanya upaya peningkatan disiplin kerja yang dilakukan oleh pimpinan Sekretariat Daerah Kota Palu Provinsi Sulawesi Tengah untuk memberikan reward atau penghargaan, adanya upaya pimpinan Sekretariat Daerah Kota Palu Provinsi Sulawesi Tengah untuk melakukan evaluasi kepada pegawai-pegawai menindak atau memberikan sanksi kepada pegawai yang melanggar disiplin kerja pegawai, dan adanya upaya pimpinan di Sekretariat 
Daerah Kota Palu Provinsi Sulawesi Tengah untuk memberikan pelatihan pembinaan bagi pegawai di Sekretariat Daerah Kota Palu Provinsi Sulawesi Tengah. Sehingga dapat dikatakan meningkatnya disiplin kerja pegawai di Sekretariat Daerah Kota Palu Provinsi Sulawesi Tengah apabila pengupayaanpengupayaan tersebut dapat dilakukan dengan baik sesuai dengan peraturan-peraturan yang berlaku untuk lebih meningkatkan disiplin kerja pegawai di Sekretariat Daerah Kota Palu Provinsi Sulawesi Tengah.

\section{KESIMPULAN}

Bahwa untuk memberikan jawaban terhadap bagaimana disiplin kerja pegawai di Sekretariat Daerah Kota Palu Provinsi Sulawesi Tengah, dapat disimpulkan berdasarkan Kehadiran, Ketaatan pada peraturan kerja Ketaatan pada standar kerja, Tingkat kewaspadaan tinggi dan Bekerja Etis. Adapun faktor-faktor peningkatan sebagai berikut: Kompensasi, Keteladanan Pimpinan, Peraturan Disiplin Kerja, Ketegasan Pimpinan, Pengawasan, Perhatian Pimpinan, dan Kebiasaan-kebiasaan tegaknya disiplin

Upaya Perningkatan Disiplin Kerja Pegawai di Sekretariat Daerah Kota Palu Provinsi Sulawesi Tengah yaitu Adanya upaya pimpinan atau pejabat struktural untuk selalu memberikan arahan atau himbauan kepada pegawai untuk selalu menaati Peraturan Disiplin Kerja., melengkapi sistem software pada alat fingerprint, Pemerintah Kota Palu Provinsi Sulawesi Tengah untuk menganggarkan penambahan penghasilan bagi pegawai yang tidak menduduki Jabatan Struktural dalam lebih meningkatkan disiplin kerja pegawai di Sekretariat Daerah Kota Palu Provinsi Sulawesi Tengah, peningkatan disiplin kerja yang dilakukan oleh pimpinan Sekretariat Daerah Kota Palu Provinsi Sulawesi Tengah untuk memberikan reward atau penghargaan, pimpinan Sekretariat Daerah Kota Palu Provinsi Sulawesi Tengah untuk melakukan evaluasi kepada pegawai-pegawai menindak atau memberikan sanksi kepada pegawai yang melanggar disiplin kerja pegawai, dan pimpinan di Sekretariat Daerah Kota Palu Provinsi Sulawesi Tengah untuk memberikan pelatihan pembinaan bagi pegawai .

\section{DAFTAR PUSTAKA}

Arikunto, Suharsimi. 2010. Prosedur Penelitian Suatu Pendekatan Praktis. Jakarta: Rineka Cipta.

Djaenuri, M. Aries.2014. Modul 1 KonsepKonsep Dasar Pemerintahan Daerah. Sumedang: IPDN Press

Fahmi, Irham. 2016. Pengantar Manajemen Sumber Daya Manusia Konsep \& Kinerja. Jakarta: Mitra Wacana Media.

Gie, The Liang. 2000. Administrasi Perkantoran. Yogyakarta: Modern Liberty.

Gomes, Cardoso Faustino. 1997. Manajemen Sumber Daya Manusia. Yogyakarta: Andi Offset.

Hamdi, Muchlis. 2002. Bunga Rampai Pemerintahan. Jakarta: Yasref Watampone.

Hasibuan, Malayu S.P. 2013. Manajemen Sumber Daya Manusia Edisi Revisi, Jakarta: Bumi Aksara.

Hasibuan, Malayu, S.P. 2008. Organisasi \& Motivasi Dasar Peningkatan Produktivitas. Jakarta: PT. Bumi Aksara.

Hasibuan, Malayu, S.P. 2016. Manajemen Sumber Daya Manusia. Jakarta: PT. Bumi Aksara.

Irawan, Prasetya. 2004. Logika dan Prosedur Penelitian. Jakarta: STIA-LAN Press.

Kaswan, 2012. Manajemen Sumber Daya Manusia untuk Keunggulan Bersaing Organisasi. Yogyakarta: Graha Ilmu.

Labolo, Muhadam. 2011. Memahami Ilmu Pemerintahan. Jakarta: PT. RajaGrafindo Persada.

Mahmudi, 2015. Manajemen Kinerja Sektor Publik Edisi Kedua. Yogyakarta: UPP STIM YKPN.

Mangkunegara, Anwar Prabu. 2011. Manajemen Sumber Daya Manusia Perusahaan. Bandung: PT. Remaja Rosadakarya.

Martoyo, Susilo. 2000. Manajemen Sumber Daya Manusia Edisi Keempat. Yogyakarta: BPFE Anggota IKAPI.

Marwansyah, 2016. Manajemen Sumber Daya Manusia. Bandung: Alfabeta.

Moleong. 2017. Metodologi Penelitian Kualitatif. Bandung: PT. Remaja Rosdakarya.

Mulyadi, M. 2016. Metode Penelitian Praktis: Kuantitatif dan Kualitatif. Jakarta: Publica Press.

Noor, Juliansyah. 2012. Metodologi Penelitian. Jakarta: Kencana Prenada Media Group. 
Peraturan Pemerintah Republik Indonesia Nomor 53 Tahun 2010 tentang Disiplin Pegawai Negeri Sipil.

Peraturan Wali Kota Palu Nomor 3 Tahun 2013 tentang Disiplin Kerja Pegawai Negeri Sipil dilingkungan Pemerintah Daerah Kota Palu Provinsi Sulawesi Tengah.

Peraturan Wali Kota Palu Nomor 35 Tahun 2015 tentang Tambahan Penghasilan Pegawai Negeri Sipil dilingkungan Pemerintah Daerah Kota Palu.

Purwanegara, Djumhana, dkk. 2009. Pengembangan Sumber Daya Manusia (Human Resources Development) Teori dan Dinamika Praktik. Bandung: CV. Dea Art Pustaka.

Rivai, Veithzal. 2009. Manajemen Sumber Daya Manusia Untuk Perusahaan Dari Teori Praktik. Jakarta: Raja Grafindo Persada.

Sastrohadiwiryo, dan Syuhada. 2019. Manajemen Tenaga Kerja Indonesia Pendekatan Administratif dan Operasional. Jakarta: Bumi Aksara.

Saydam, Gouzali. 2000. Manajemen Sumber Daya Manusia:Suatu Pendekatan Mikro. Jakarta: Djambatan.

Sedarmayanti. 2010. Manajemen Sumber Daya Manusia, Reformasi Birokrasi dan Manajemen Pegawai Negeri Sipil, Cetakan Ke Empat. Bandung: PT. Refika Aditama.
Siagian, Sondang. P. 2016. Manajemen Sumber Daya Manusia. Jakarta: PT. Bumi Aksara.

Simamora, Henry. 2010. Manajemen Sumber Daya Manusia. Edisi Satu. Yogyakarta: STIE YKPN.

Sinambela, Poltak Lijan. 2018. Manajemen Sumber Daya Manusia: Membangun Tim Kerja Solid Untuk Meningkatkan Kinerja. Jakarta: PT. Bumi Aksara.

Sutrisno, Edy. 2017. Manajemen Sumber Daya Manusia. Jakarta: Kencana.

Sulistiyani, Teguh Ambar \& Rosidah. 2009. Manajemen Sumber Daya Manusia Konsep, Teori dan Pengembangan Dalam Konteks Organisasi Publik. Yogyakarta: Graha Ilmu.

Sugiyono. 2011. Metode Penelitian Kuantitatif, Kualitatif dan $R \& D$. Bandung: Alfabeta.

Sukarna. 2011. Dasar-Dasar Manajemen. Bandung: CV. Mandar Maju.

Susanto, Astrid. S. 1974. Komunikasi Dalam Teori dan Praktek. Jakarta: Bina Aksara.

Usman, Husaini dan Purnomo Setiady Akbar. 2009. Metodology Penelitian Sosial. Jakarta: Bumi Aksara.

Undang-Undang Nomor 5 Tahun 2014 tentang Aparatur Sipil Negara.

Wibowo. 2012. Manajemen Kinerja. Jakarta: PT. RajaGrafindo Persada. 